\title{
An overlooked invasive alien plant of Jejudo Island: Commelina caroliniana (Commelinaceae)
}

\author{
Eun Su KANG, Kang-Hyup LEE and Dong Chan SON* \\ Division of Forest Biodiversity and Herbarium, Korea National Arboretum, Pocheon 11186, Korea \\ (Received 28 December 2020; Revised 22 February 2021; Accepted 6 March 2021)
}

\begin{abstract}
Invasive alien species management is pivotal for biodiversity conservation. Commelina caroliniana Walter, from the family Commelinaceae, is an alien plant native to the Himalayas and India, but it has been widely introduced around the world, including in the United States, Brazil, Philippines, and Japan. In Korea, the first population was found growing adjacent to agricultural land and farm roads on Jejudo Island, and field observations confirmed the presence of at least nine populations there. It is similar morphologically to $C$. diffusa Burm. f. but can be distinguished by involucral bracts that are ciliate at the base, hairs on the peduncle and obsolete upper cincinnus, brown spots on its 4-lobed antherode, and seed surfaces that are smooth to slightly alveolate. It was determined to have an invasiveness low score of 8 according to the Korean 'Invasive Alien Plant Risk Assessment', suggesting that it may spread to natural habitats. Although the current distribution of $C$. caroliniana is restricted to Jeju-si, it has spread dramatically in many other areas of the world. At present, it has had a limited impact on the local environment, but local and regulatory authorities should pay close attention to this plant and take measures to prevent its expansion in the future.
\end{abstract}

Keywords: Commelina caroliniana, C. diffusa, invasive alien plant, Invasive Alien Plant Risk Assessment

Commelinaceae Mirb. is a relatively large family, containing 41 genera and 650 species worldwide (Hong, 2000; Lee, 2006; Gajurel and Shrestha, 2009; Fukuoka and Iwatsuki, 2016; Ezeabara et al., 2019). The family is morphologically characterized by a prominent sheath or involucral bracts with a leaf blade containing moisture, and a flower split into three parts (Evans et al., 2000; Hong, 2000; Fukuoka and Iwatsuki, 2016).

Commelinaceae was initially classified into two families, Commelineae and Tradescantieae, by Meisner (1842). Later, Faden and Hunt (1991) divided Commelinaceae into two subfamilies, Cartonematoideae and Commelinoideae, and included two tribes, Commelineae and Tradescantieae, within Commelinoideae. Additionally, Evans et al. (2000) used a molecular approach to show the cladogram for the Commelinaceae family.

In the family Commelinaceae, the largest genus is Commelina L., which consists of approximately 170 species
(Kaul and Koul, 2012; Nandikar and Gurav, 2018) and it is particularly diverse in Africa where there are 120 species (Faden, 2012). However, the identity of some species is unclear due to nomenclatural and taxonomic problems such as the absence of a type specimen and lack of detailed morphological descriptions in the protologue (Faden, 1989). Furthermore, Commelina is an increasingly confusing genus, as new species are continuously described without taxonomic verification based on the characteristics of the vegetative organs or the physiology of previously accepted taxa (Hassemer, 2019). In Korea, C. benghalensis L. and C. diffusa Burm.f. (Kim and Kim, 2011) have recently been identified as alien species. There are five taxa (Lee, 2003; Lee, 2006; Lee, 2007; Korea National Arboretum, 2017, 2019; Lee, 2018), known to occur in various habitats (Hong, 2000; Fukuoka and Iwatsuki, 2016; Lee, 2018).

During a recent field survey of alien plants on Jejudo Island, we discovered an unusual and rather isolated population of Commelina in Jongdal-ri of Jeju-si (Fig. 1), which appeared

\footnotetext{
*Author for correspondence: sdclym@korea.kr
} 


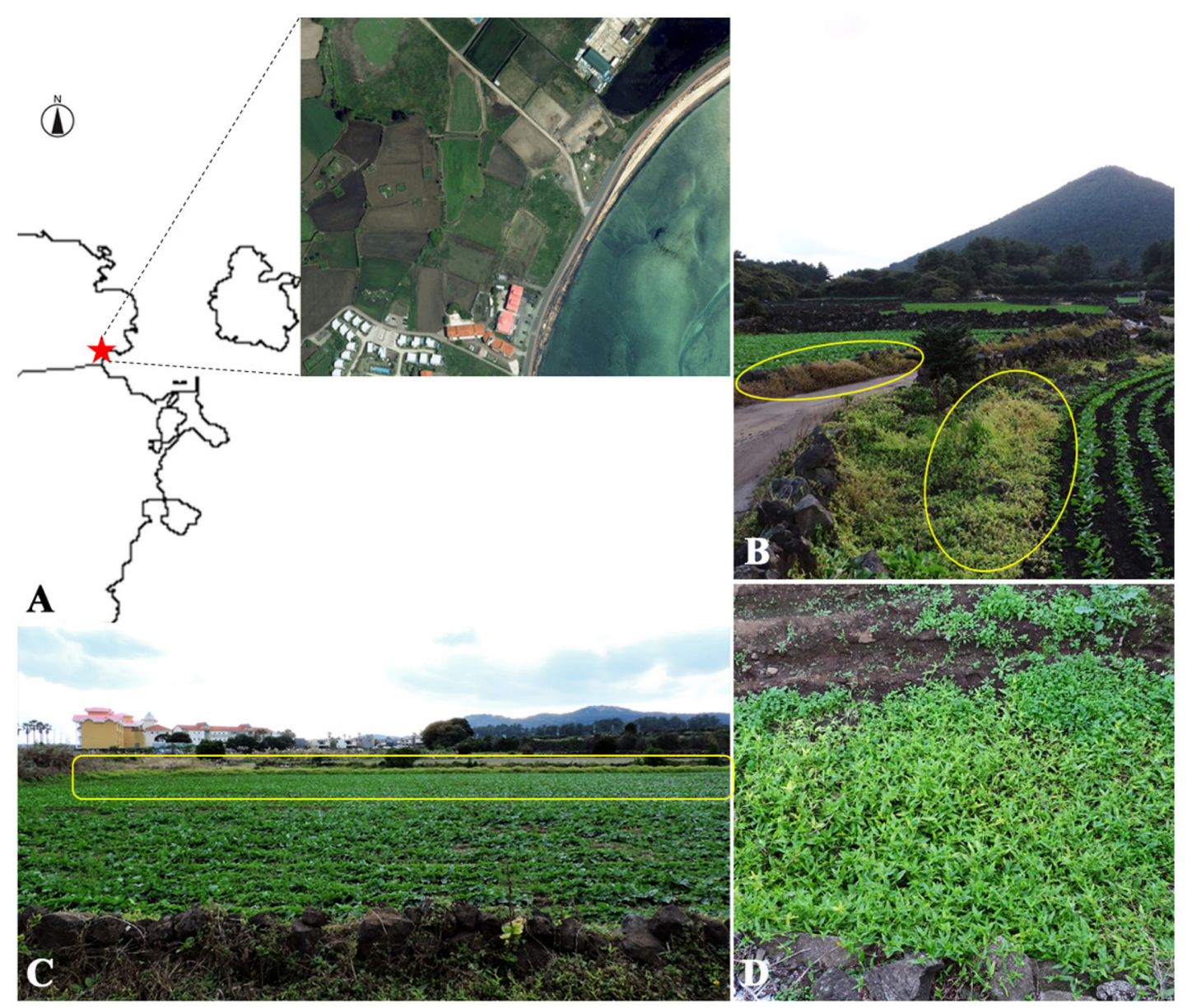

Fig. 1. Commelina caroliniana Walter, which was found in Jongdal-ri, Jeju-si, Jeju-do. A. Collection site of Commelina spp. B. Habitat of $C$. caroliniana, which was first found in October, 2019. C. Commelina caroliniana spreading along the agricultural land and farm road. D. Commelina caroliniana population forming dense mats.

to be morphologically differentiated from the other Commelina taxa previously recorded in the flora of Korea (Lee, 2003; Lee, 2006; Lee, 2007; Kim and Kim, 2011; Lee, 2018). After examining various floras and herbarium specimens from Korea and adjacent countries as well as the relevant literature (Faden, 1989, 1993, 2000; Hong, 2000; Lee, 2003; Lee, 2006; Kaul et al., 2007; Lee, 2007; Kim and Kim, 2011; Nampy et al., 2013; Joseph and Nampy, 2015; Fukuoka and Iwatsuki, 2016; Korea National Arboretum, 2017; Lee, 2018; Nandikar and Naik, 2019), it was concluded that the collected specimens were $C$. caroliniana Walter, a species native to Himalaya and India that has been introduced into many areas of the world, including the United States, Brazil, Philippines, Guyana, and Japan. Here, we have provided a detailed description, and color photographs of this newly recorded invasive alien plant in the flora of Korea, and this information could be utilized to help effectively manage it.

\section{Materials and Methods}

Morphological observations of the new alien species were conducted on living plants and herbarium specimens in 2019 and 2020. The field photographs were captured with a Nikon Coolpix P510 camera (Tokyo, Japan). The morphological characteristics were measured using a Mitutoyo 500-196-30 absolute digimatic Vernier caliper (Kanagawa, Japan), and the data were derived from the field notes. The flowering and fruiting periods were given as cited on the collector's labels. The examined material has been deposited in the Korea National Arboretum (KH). To confirm the identity of $C$. diffusa in Korea, we investigated the habitat (Yongdam-dong, Jeju-si), which was reported by Kim and Kim (2011) and voucher specimens of $C$. diffusa that were stored at the National Institute of Biological Resources (KB). The invasiveness status was assessed by applying the Invasive Alien Plant Risk Assessment 
system (Jung et al., 2015).

\section{Results}

Commelina caroliniana Walter, Fl. Carol. 68, 1788.-TYPE: U.S.A. South Carolina, Walter (or Fraser?) s.n., Walter Herbarium, p. 35, upper right-hand corner (lectotype, BM!, designated by Faden, 1989) (Fig. 2).

Commelina hasskarlii C.B.Clarke, Commelyn. Cyrtandr. Bengal. 13, t. 3, 1874.

Korean name: Nu-un-dak-ui-jang-pul (누운닭의장풀).

Herbs annual, diffusely spread. Rhizome absent; roots at the nodes. Stems decumbent to scandent, branched at basal, more than $1 \mathrm{~m}$ long, glabrous. Leaves alternate, sessile or subsessile; sheath hispid-ciliate, with green to red veins; blade lanceolate or lanceolate-oblong, 2.2-6.2 cm long, 0.7-1.5 cm wide, apex acute, margin entire, base cordate or rounded, light green, glabrous. Inflorescence cincinni included in involucral bract, dichotomously branched from base; upper cincinnus mostly obsolete and short, rarely with $1.5-2 \mathrm{~cm}$ long pedicel exerted from involucral bracts, male flower 1 ; other cincinnus with much shorter pedicel, bisexual flowers 1-2. Involucral bracts opposite to leaf, spathe-like, folded or slightly funnel-form, basal detached, 1.2-2.5 cm long, 1.25-1.7 cm wide, apex acuminate, entire to repand, abaxially glabrous or sparselypubescent, ciliate at base; peduncle pubescent. Flowers zygomorphic, andromonoecious; inner sepals 2, often connate at base, ovate-orbicular, 3-4 mm long, membranous; petals 3, free, blue, spatulate or orbicular, longer ones $2,8-11 \mathrm{~mm}$ long, 7-10 mm wide, small one 1, 6-8 mm long, 4-5 mm wide; fertile stamens 3 , longer ones 2 , shorter one 1; filaments glabrous; staminodes 3, 4-lobed, butterflylike, antherodes developed; antherodes with brown spot or absent; ovary 3loculed, posterior locule 1, ovule 1, anterior locules 2, each ovules 2. Fruit capsule, ellipsoid, 4-7 mm long, 5-6 mm wide, light green, 3-valved; posterior valve 1-seed, indehiscent; anterior valve 2, each 2 seeds, dehiscent. Seeds brown to dark brown, smooth to slightly alveolate surface; longer ones 4-4.8 $\mathrm{mm}$ long, 1.6-2 mm wide, oblong; small 2.8-3 mm long, 1.6$2 \mathrm{~mm}$ wide, ovate-spherical, truncate at base.

Phenology: August to September, usually begins to bloom after the rainy season.

Distribution: Bangladesh, Brazil, Guyana, India, Japan, Korea (Jejudo Island), Nepal, Philippines, United States.

Specimens examined: GUYANA. Georgetown, 3 Jun 1987, B. Boom, M. Blackman and R. Mohabir, 01392710 (NY).

KOREA. Jeju-do: Jeju-si, Jongdal-ri, 30 Oct 2019, KH1910301, KH1910302, KH1910303, KH1910304 (KH); 10 Sep 2020, KESUA0003, KESUA0004, KESUA0005, KESUA0006 (KH); Jeju-si, Yongdam 3(Sam)-dong, 14 Sep 2019, NIBRVP0000759501, NIBRVP0000759502 (KB); 5 Oct 2019, NIBRVP0000759503, NIBRVP0000759504 (KB); 10 Sep 2020, KESUA0001 (KH); Jeju-si, Hado-ri, 10 Sep 2020, KESUA0002 (KH); Seogwipo-si, Sagye-ri, 10 Oct 2020, KJS0691 (KH).

NEPAL: Dhankuta, 21 Oct 1963, H. Hara, H. Kanai, S. Kurosawa, G. Murata, M. Togashi and T. Tuyama, 10002301 (TI).

U.S.A. Florida: Jacksonville, 2 Oct 1893, A. H. Curtiss, 03733347, 03733348 (NY); Louisiana: New Orleans, 16 Oct 1989, Toby Feibelman, 03733334 (NY); Louisiana: Cameron, 18 Nov 1983, R. Dale Thomas, B. E. Dutton and D. D. Taylor, 03733350 (NY); Louisiana: Medison, 8 Nov 1983, R. Dale Thomas, 03733351 (NY).

Taxonomic note: Commelina caroliniana is morphologically similar to $C$. diffusa by having creeping and diffusely spreading stems on the ground, acuminate apex in the involucral bracts (Fig. 2A, B), and the five seeds contained in the three-locular capsule (Fig. 2I) (Faden, 1989, 1993). Despite these similarities, there are clear differences between the two species, such as the shape of the involucral bracts, the trichomes of the involucral bracts and peduncle, the number of flowers on the upper cincinni, the presence of a brown spot on the central part of the antherode in the staminodes, the surfaces and color of the

Table 1. Morphological differences between C. caroliniana and C. diffusa.

\begin{tabular}{|c|c|c|}
\hline Character & C. caroliniana & C. diffusa \\
\hline Involucral bracts & $\begin{array}{l}\text { Not at all to slightly falcate and margins usually ciliate basally, } \\
\text { hairs on the peduncle }\end{array}$ & $\begin{array}{l}\text { Usually distinctly falcate and margins glabrous or } \\
\text { ciliolate (rarely ciliate), peduncle glabrous }\end{array}$ \\
\hline Upper cincinni & $\begin{array}{l}\text { Usually short and obsolete, not exerted from involucral bract; } \\
\text { pedicel rarely developed, unbranched, with absent or } 1 \text { male } \\
\text { flower bloom }\end{array}$ & $\begin{array}{l}\text { Present, exerted from involucral bract; } \\
\text { pedicel well-developed, branched, with 1-4 male or } \\
\text { bisexual flower blooms }\end{array}$ \\
\hline Staminode & $\begin{array}{l}\text { Staminode 3, antherode is yellow and usually has a brown spot } \\
\text { at the center }\end{array}$ & $\begin{array}{l}\text { Staminode } 2-3 \text {, antherode is entirely yellow } \\
\text { without a brown spot at the center }\end{array}$ \\
\hline Seed & Smooth to slightly alveolate, brown to dark brown & Deeply reticulate, dark brown to black \\
\hline
\end{tabular}




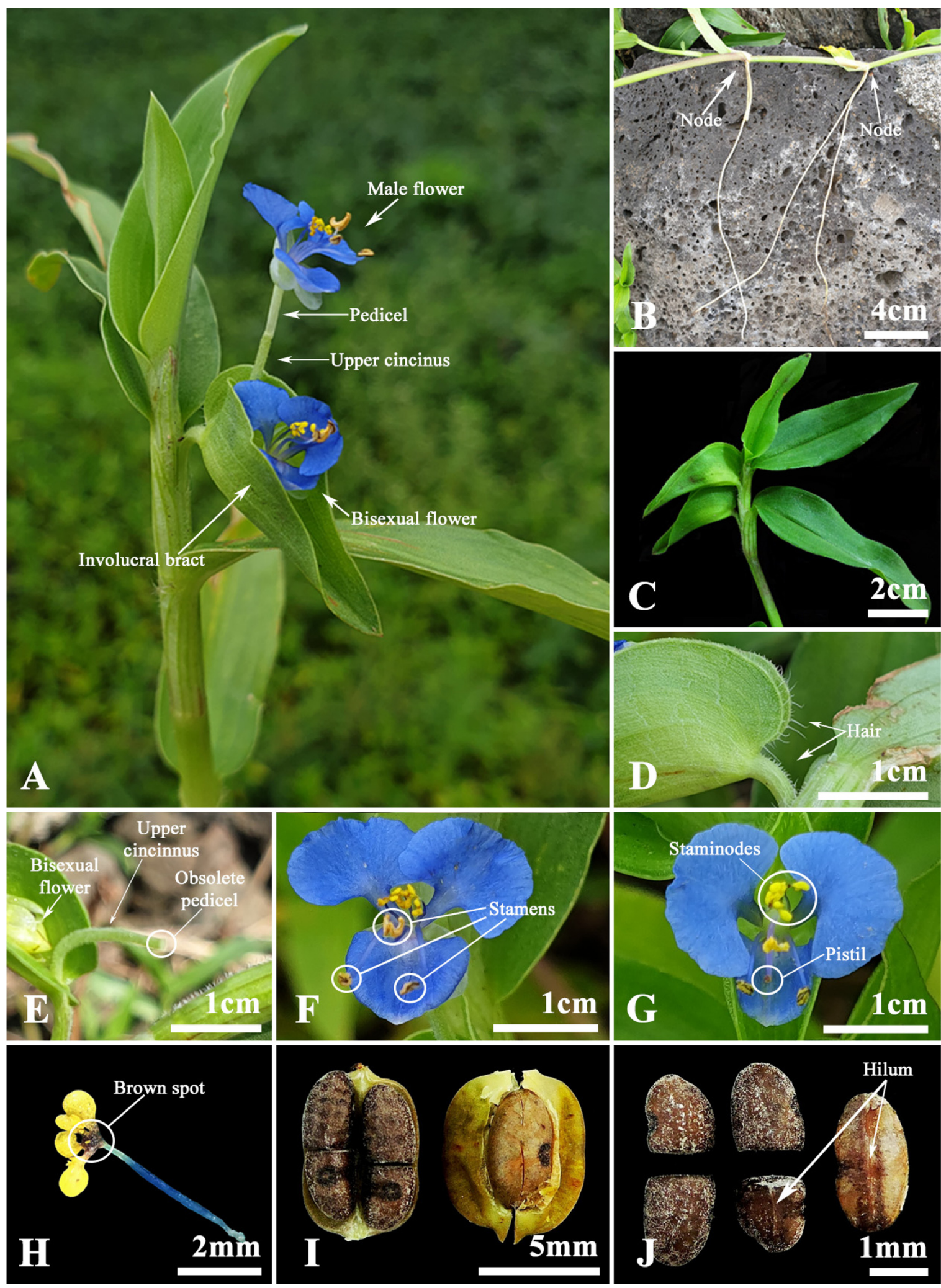

Fig. 2. Photographs of C. caroliniana from Jejudo Island, Republic of Korea. A. Polygamous plant. B. Roots at nodes. C. Leaves. D. Ciliate at base of spathe-like involucral bracts. E. Upper cincinnus exerted from involucral bracts (pedicel of apical upper cincinnus is mostly obsolete and short, rarely with $1.5-2 \mathrm{~cm}$ long pedicel). F. Male flower. G. Bisexual flower. H. Staminode (brown spot at the center of antherodes in staminode). I. Capsules (right, posterior valve with 1-seed; left, 2 anterior valves each with 2 -seeds). J. Seeds. 
seeds, as well as the chromosome numbers $(2 n=30$ for $C$. diffusa vs. $2 n=86$ for C. caroliniana) (Faden, 1989, 1993; Nandikar and Naik, 2019) (Table 1, Fig. 2).

\section{Habitat and ecology}

Based on field observations, at least nine populations of this species were observed on Jejudo Island, Korea. They either formed dense mono-species stands or stands mixed with native plants, including C. communis L., Phyllanthus urinaria L., Acalypha australis L., Humulus scandens (Lour.) Merr., Euphorbia humifusa Willd. ex Schltdl., Lactuca indica L., and alien plants, Erigeron floribundus (Kunth) Sch. Bip., and Veronica persica Poir. in a herbaceous layer.

\section{Invasiveness risk assessment in forests}

Commelina caroliniana originates in Himalaya and India and has recently been identified as an invasive alien plant in the United States and Japan. In the study, C. caroliniana was assigned a slightly low invasiveness score of 8 , suggesting that the potential invasion is minor in the forest, according to the classification by Jung et al. (2015). It is a casual alien plant mainly distributed in agricultural land and lowland farm roads, forming dense mats. Each population identified included over 200 mature individuals that seemed to have been naturalized plants as they formed a sustainable population growing naturally with the native plants in herbaceous layers. It is difficult to trace how this species was introduced to Korea, but considering the environment of the habitat, we can assume that it was unintentionally introduced after being mixed with rice or other crops planted in the fields. Although the current nine habitats identified for $C$. caroliniana were restricted to agricultural land and farm roads in Jeju-do Province, these areas are prone to invasion of alien plant species owing to their frequent exposure to stress and disturbance (Kim et al., 2019); thus, as this species has a strong ability to spread, it may cause difficulties in the future for agricultural land management. Furthermore, there is evidence that it has spread dramatically in many other areas of the world. Therefore, local and regulatory authorities should pay close attention to this plant and take measures to stop its expansion.

\section{Key to the species of Commelina in Korea}

1. Proximal margin of involucral bracts connate

C. benghalensis

1. Proximal margin of involucral bracts open or folded but not basally connate, rounded.

2. Involucral bracts funnel-formed; locules of capsule 3, seeds 5 C. caroliniana

2. Involucral bracts cardioid-shaped; locules of capsule 2, seeds 4

3. Flower less than $1 \mathrm{~cm}$ in diam. C. minor

3. Flower more than $1 \mathrm{~cm}$ in diam.

4. Leaves broadly lanceolate; proximal petal white .

C. communis var. communis

4. Leaves lanceolate; proximal petal light blue ….... C. communis var. angustifolia

\section{Discussion}

Commelina caroliniana is native to Himalaya and India, but was first reported in South Carolina, United States, where it was known to be introduced during the importation of grain in 1696 (Rehel, 2013). Currently, the original habitat of $C$. caroliniana is gradually disappearing due to urban development, whereas in the United States, it is widely naturalized in the southeast and has been designated as an invasive alien plant that damages crops (Faden, 1993; Rehel, 2013; Kraus et al., 2020). Commelina caroliniana is also naturalized in Japan, and it is speculated that it was introduced to Kyushu during the importation of rice from India (Matsuo et al., 2016).

Previously, the identity of $C$. caroliniana was unclear and overlooked, and it was treated as a synonym of $C$. diffusa (Clarke, 1881; Britton and Brown, 1896; Pennell, 1938; Brashier, 1966; Duncan and Kartesz, 1981) as they are morphologically very similar, and $C$. diffusa is more widely distributed in the world than C. caroliniana. However, Faden (1989, 1993) detected them to be different species by distinguishing differences in their external morphologies such as their involucral bracts, cincinni, staminodes, seeds, and the number of chromosomes (see Table 1).

Commelina diffusa was recently reported as an unrecorded alien species by Kim and Kim (2011) and was confirmed as being misidentified as $C$. caroliniana. In the images of $C$. diffusa presented by Kim and Kim (2011), there were hairs on the peduncle and ciliate of the basal involucral bracts, which are major characteristics of $C$. caroliniana. Not only that, but the seed had a slightly uneven surface, it was almost smooth, unlike the $C$. diffusa presented by Faden (1993). Furthermore, all four specimens of $C$. diffusa deposited at KB (NIBRVP0000759501, NIBRVP0000759502, NIBRVP0000759503, NIBRVP0000759504) have hairs on the peduncle and cilia at the basal involucral bracts (Fig. 3B), and the upper cincinnus in the involucral bracts are obsolete and short (Fig. 3E). Moreover, two sheets (NIBRVP0000759501, NIBRVP0000759502) which had flowers (Figs. 3A, D), displayed brown spots on 


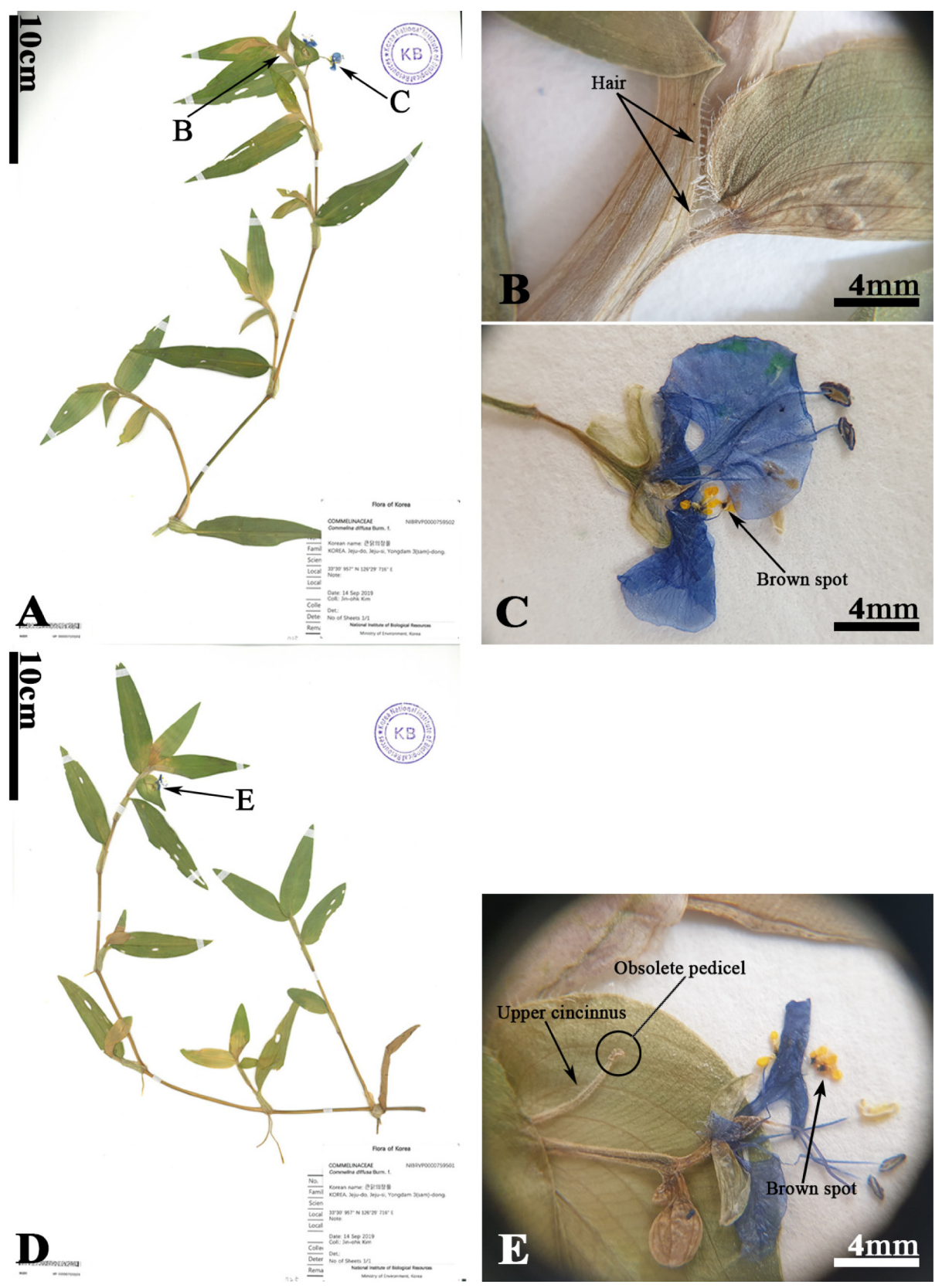

Fig. 3. Voucher specimens, which are registered as C. diffusa at the National Institute of Biological Resources (KB). A. NIBRVP0000759502 B. Ciliate at base of involucral bracts and hairs on peduncle. C. Brown spot at the center of the antherode in the staminode. D. NIBRVP0000759501 E. Obscure pedicel at upper cincinnus and brown spot at the center of the antherode in the staminode.

the center of the antherode, which were not observed in $C$. diffusa (Figs. 3C, E). When we carried out investigations in Yongdam-dong, Jejudo Island, where $C$. diffusa was first found in Korea, $C$. diffusa could not be identified, but $C$. caroliniana along with $C$. communis were (Fig. 4). Therefore, we concluded that Kim and Kim (2011) potentially misidentified C. caroliniana as $C$. diffusa, and that $C$. diffusa is not distributed in Korea.

Meanwhile, it is presumed that C. caroliniana in Jejudo Island was unintentionally introduced after being mixed with rice or other crops planted in the fields, as occurred previously in the United States and Japan. This species seems to have been naturalized for a long time ago as it was reported in 2011 by $\mathrm{Kim}$ and $\mathrm{Kim}$ (2011) as C. diffusa, and currently, $C$. 


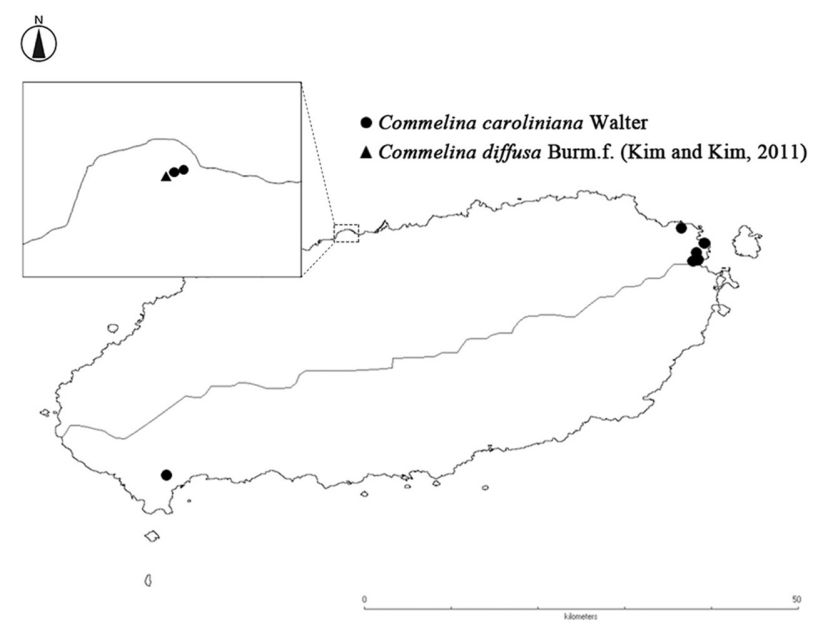

Fig. 4. Distribution map of Commelina caroliniana Walter from Jejudo Island, Korea. Triangle identifies the location, reported by Kim and Kim (2011) to contain C. diffusa Burm. f.

caroliniana is extensively distributed in Jejudo Island (Fig. 4).

In Korea, ecosystem damage caused by $C$. caroliniana has not yet been reported, but the possibility that $C$. caroliniana can spread to the surrounding farmland or natural ecosystem and cause damage cannot be completely neglected, as seen in the United States. Therefore, it is necessary to identify the possibility of spread and ecological impact, conduct periodic distribution surveys, and prepare measures to mitigate damage if necessary.

ORCID: Eun Su KANG: https://orcid.org/0000-0003-34990869; Kang-Hyup LEE: https://orcid.org/0000-0002-71893235; Dong Chan SON: https://orcid.org/0000-0002-67730580

\section{Acknowledgments}

This study was supported by the Korea National Arboretum, project No. KNA1-2-39, 21-2.

\section{Conflict of Interest}

The authors declare that there are no conflicts of interest.

\section{Literature Cited}

Brashier, C. K. 1966. A revision of Commelina (Plum.) L. in the U.S.A. Bulletin of the Torrey Botanical Club 93: 1-19.

Britton, N. L. and A. Brown. 1896. An Illustrated Flora of the Northern United States, Canada and the British Possessions,
Vol. 1. Charles Scribner's Sons, New York, 612 pp.

Clarke, C. B. 1881. Commelinaceae. In Monographiae Phanerogamarum, Vol. 3. Candolle, A. D. and B. D. Candolle (eds.), Sumptibus G. Masson, Paris. Pp. 113-324.

Duncan, W. and J. T. Kartesz. 1981. Vascular Flora of Georgia: An Annotated Checklist. University of Georgia Press, Athens, GA, $160 \mathrm{pp}$.

Evans, T. M., R. B. Faden, M. G. Simpson and K. J. Sytsma. 2000. Phylogenetic relationships in the Commelinaceae: IA cladistic analysis of morphological data. Systematic Botany 25: 668691.

Ezeabara, C. A., E. M. Chukwu and C. U. Okeke. 2019. Phytochemical and proximate studies of various parts of Commelina benghalensis L. and Commelina diffusa Burm. f. International Journal of Plant Science and Ecology 5: 43-46.

Faden, R. B. 1989. Commelina caroliniana (Commelinaceae): a misunderstood species in the United States is an old introduction from Asia. Taxon 38: 43-53.

Faden, R. B. 1993. The misconstrued and rare species of Commelina (Commelinaceae) in the eastern United States. Annals of the Missouri Botanical Garden 80: 208-218.

Faden, R. B. 2000. Commelinaceae. In Flora of North America, Vol. 22. Morin, N. R. (ed.), Oxford University Press, New York. Pp. 192-197.

Faden, R. B. 2012. Commelinaceae. In Flora of Tropical East Africa. Beentje, H. (ed.), Royal Botanic Gardens, Kew. Pp. 203-204.

Faden, R. B. and D. R. Hunt. 1991. The classification of the Commelinaceae. Taxon 40: 19-31.

Fukuoka, N. and K. Iwatsuki. 2016. In Flora of Japan, Vol. 4b. Iwatsuki, K., D. E. Boufford and H. Ohba (eds.), Kodansha, Tokyo. Pp. 46-51.

Gajurel, J. P. and K. K. Shrestha. 2009. Taxonomy of the genus Commelina Plum. ex L. (Commelinaceae) in Nepal. Botanica Orientalis: Journal of Plant Science 6: 25-31.

Hassemer, G. 2019. Further advances to the nomenclatural, taxonomic and geographic knowledge of the New World Commelina (Commelinaceae): toward a continental treatment. Phytotaxa 400: 89-122.

Hong, D. 2000. Commelinaceae. In Flora of China, Vol. 24. Wu, Z. Y. and R. H. Raven (eds.), Science Press, Beijing and Missouri Botanical Garden Press, St. Louis, MO. Pp. 39-133.

Joseph, S. M. and S. Nampy. 2015. Spathe morphology of Commelina L. (Commelinaceae) of India in relation to taxonomy. Botanica Orientalis: Journal of Plant Science 9: 1-11.

Jung, J. M., S. Y. Jung, S. H. Park, J. C. Yang, K. Choi, S. H. Oh and C. H. Shin. 2015. Invasive Alien Plant Impact on Forest. Korea National Arboretum, Pocheon, 280 pp. (in Korean) 
Kaul, V. and A. K. Koul. 2012. Staminal variation and its possible significance in Commelina benghalensis L. and Commelina caroliniana Walter. Current Science 103: 419-426.

Kaul, V., A. K. Koul and N. Sharma. 2007. Genetic system of two rainy season weeds: Commelina benghalensis L. and Commelina caroliniana Walter. Chromosome Botany 2: 99-105.

Kim, C.-S. and S.-Y. Kim. 2011. Two new records for the Korean flora: Commelina benghalensis L. and C. diffusa Burm. f. (Commelinaceae). Korean Journal of Plant Taxonomy 41: 5865. (in Korean)

Kim, H.-W., D. C. Son, S. H. Park, C.-S. Jang, E.-M. Sun, H. Jo, S. M. Yun and K. S. Chang. 2019. Unrecorded alien plant in South Korea: Ludwigia peploides subsp. montevidensis (Spreng.) P.H. Raven. Korean Journal of Plant Resources 32: 201-206. (in Korean)

Korea National Arboretum. 2017. Checklist of Vascular Plants in Korea. Korea National Arboretum, Pocheon, 1000 pp. (in Korean)

Korea National Arboretum. 2019. Checklist of Alien Plants in Korea. Korea National Arboretum, Pocheon, 225 pp. (in Korean)

Kraus, F., W. Daniel, L. J. Wong and S. Pagad. 2020. Global Register of Introduced and Invasive Species-United States of America (Contiguous). Version 1.1. Invasive Species Specialist Group ISSG. Retrieved Nov. 9, 2020, available from https:// doi.org/10.15468/ehzr9f.

Lee, N. S. 2007. Commelinaceae. In The Genera of Vascular Plants of Korea. Flora of Korea Editorial Committee (ed.), Academy Publishing Co., Seoul. Pp. 1098-1101.
Lee, N. S. 2018. Commelinaceae. In The Genera of Vascular Plants of Korea. Flora of Korea Editorial Committee (ed.), Hongreung, Seoul. Pp. 1460-1464. (in Korean)

Lee, T. B. 2003. Coloured Flora of Korea, Vol. 2. Hayangmunsa, Seoul, 910 pp. (in Korean)

Lee, Y. N. 2006. New Flora of Korea, Vol. II. Kyo-hak Publishing Co., Ltd., Seoul, 885 pp. (in Korean)

Matsuo, M., T. Sakai and Y. Kawano. 2016. Seed heteromorphism in Carolina dayflower (Commelina caroliniana Walter). Weed Biology and Management 16: 169-176.

Meisner, C. F. 1842. CCLXI Commelinaceae. In Plantarum Vascularium Genera, Vol. 1. Weidmann, Leipzig. Pp. 406-407.

Nampy, S., S. M. Joseph and K. M. Manudev. 2013. The genus Commelina (Commelinaceae) in Andaman \& Nicobar Islands, India with one new species and three new records. Phytotaxa 87: 19-29.

Nandikar, M. D. and R. V. Gurav. 2018. A new species of Commelina (Commelinaceae) from India. Journal of Plant Taxonomy and Geography 73: 233-237.

Nandikar, M. D. and M. C. Naik. 2019. Commelina littoralis (Commelinaceae), a new species from India. Nordic Journal of Botany 37: e02168.

Pennell, F. W. 1938. What is Commelina communis?. Proceedings of the Academy of Natural Sciences of Philadelphia 90: 3139.

Rehel, S. 2013. Commelina caroliniana. The IUCN Red List of Threatened Species 2013: e.T177167A7382133. Retrieved Nov. 9, 2020, available from http://dx.doi.org/10.2305/ IUCN.UK.2011-1.RLTS.T177167A7382133.en.

Appendix 1. Observed specimens Commelina diffusa Burm.f. in this study. ANTIGUA and BARBUDA. Gunthorpes, 22 Oct 1937, H. E. Box, 01503967 (NY).

BRAZIL. Sergipe: Maruim, 22 May 2013, L. A. Gomes, 02103608 (NY).

CHINA. Maguan: Gulinqing, 14 Oct 2002, Y. M. Shui W. H. Chen and J. S. Sheng, 31282 (PE); Yunnan: Luchun, 8 Aug 2006, Y. Shui and W. Chen, 70646 (PE).

CUBA. Pinar del Río: Punta Brava, 15 Nov 1904, C. F. Baker, 01503946 (NY); Havana: Santiago de Chile, 13 Nov $1904, H$. A. van Hermann, 01503924 (NY).

U.S.A. Florida: Alachua, 26 Oct 1976, D. W. Hall, 165615 (FLAS); Brevard, 20 Mar 2002, J. E. Tear, 231820 (FLAS); Alabama: Tallapoosa, 18 Oct 2006, T. W. Barger and D. Tenaglia, 00014810 (AMAL); Monroe, 11 Sep 2012, T. W. Barger and B. D. Holt, 00019555 (AMAL); Alabama: Montgomery, 20 Oct 2011, A. R. Diamond, 0010106 (UWAL).

VIRGIN ISLANDS. Saint Croix: Frederiksted, 24 Jan 1980, F. R. Fosberg, 01503969 (NY). 